\title{
Situasi Rabies pada Anjing dan Kucing di Wilayah Layanan Balai Besar Veteriner Maros Tahun 2018
}

\author{
Sulaxono Hadi ${ }^{1 *}$, Ferra Hendrawati ${ }^{1}$, Ratna Loventa Sulaxono ${ }^{1}$ \\ ${ }^{1}$ Balai Besar Veteriner Maros \\ *Corresponding author: idahonoxalus@gmail.com
}

\begin{abstract}
Abstrak
Rabies merupakan salah satu penyakit zoonosis yang masih terjadi pada beberapa propinsi di wilayah layanan Balai Besar Veteriner Maros. Beberapa kabupaten menunjukkan kasus yang meningkat dalam setahun. Pengujian terhadap sampel otak anjing dan kucing telah dilakukan menggunakan metode fluorescent antibody technique (FAT). Sampel pengujian berasal dari kiriman dinas kabupaten/kota dan diambil di lapangan dari anjing dan kucing tersangka rabies saat pelayanan aktif. Sebanyak 559 sampel otak anjing dan kucing telah diuji dengan FAT tahun 2018, 45 sampel diantaranya berasal dari kucing. Kajian retrospektif ini dimaksudkan untuk mengetahui proporsi dan ratio hasil pengujian, distribusi dan frekuensi penyakit rabies. Sebanyak 285 sampel otak anjing dan kucing menunjukkan positif rabies dari 559 sampel yang diuji, atau proporsi uji rabiesnya sebesar $50,98 \%$. Ratio uji FAT pada anjing dan kucing secara keseluruhan sebesar 51\% positif rabies, $49 \%$ negatif rabies atau 1:1. Rabies pada tahun 2018 telah terjadi di 17 kabupaten/kota, dengan frekuensi tertinggi terjadi di Kabupaten Toraja Utara. Untuk rabies pada kucing di kabupaten Toraja Utara menunjukkan proporsi sebesar 28,89\%, sedangkan pada anjing 55,33\%. Rasio uji rabies pada kucing di kabupaten Toraja Utara, $29 \%$ positif FAT dan $71 \%$ negatif FAT atau 1:2,5, sedangkan pada anjing 55\% positif FAT dan $45 \%$ negatif FAT atau 1,2:1. Berdasarkan data kasus bulanan rabies, rabies ditemukan tiap bulan dengan frekuensi tertinggi terjadi pada bulan Oktober.
\end{abstract}

Kata kunci: FAT, Negatif, Positif, Proporsi, Rabies, Rasio

\section{Abstract}

Rabies is one of the zoonotic diseases that still occur in several provinces in the service area of Maros Veterinary Services. Some district show cases that increase in a year. Testing of dog and cat brain samples has been conducted using fluorescent antibody technique (FAT). The test samples came from district/city service shipments and were taken in the field from dogs and cats suspected of rabies while active service. . A total of 559 dog and cat brain samples were tested with FAT in 2018. Of the 559 samples, 45 were from cats. This retrospective study is intended to determine the proportion and ratio of rabies test results, distribution and frequency. A total of 285 dog and cat brain samples showed rabies positive from 559 samples tested, or a proportion of rabies tests of $50.98 \%$. A total of $559 \mathrm{dog}$ and cat brain samples were tested with FAT in 2018, 45 of which came from cats. This retrospective study is intended to determine the proportion and ratio of rabies test results, distribution and frequency. A total of $285 \mathrm{dog}$ and cat brain samples showed rabies positive from 559 samples tested, or a proportion of rabies tests of $50.98 \%$. . The ratio of FAT tests in dogs and cats overall was $51 \%$ rabies positive, $49 \%$ rabies negative or 1:1. Rabies in 2018 has occurred in 17 districts / cities, with the highest frequency occurring in North Toraja District. For Rabies in cats in North Toraja District showed a proportion of $28.89 \%$, while in dogs $55.33 \%$. The ratio of rabies test in cats in North Toraja Regency, 29\% positive fat and 71\% negative FAT or 1:2,5, while in dogs $55 \%$ positive FAT and $45 \%$ negative FAT or 1,2:1. Based on monthly cases of rabies, rabies was found every month with the highest frequency occurring in October.

Keywords: FAT, Negative, Positive, Proportion, Rabies, Ratio 
Prosiding Seminar Nasional Pembangunan dan Pendidikan Vokasi Pertanian

Politeknik Pembangunan Pertanian Manokwari, 31 Juli 2021

e ISSN : 2774-1982

DOI : https://doi.org/10.47687/snppvp.v2i1.170

\section{PENDAHULUAN}

Rabies merupakan penyakit viral zoonosis yang mematikan yang disebabkan oleh rhabdovirus. Organisasi Kesehatan Hewan Dunia, Office International des Epizooties (OIE), memperkirakan setiap tahunnya 59.000 orang meninggal karena rabies. Sebanyak 150 negara terinfeksi rabies. Dampak ekonomi yang ditimbulkan berkisar 8,6 milyar dollar Amerika setiap tahun untuk vaksinasi, pengendalan populasi, kematian ternak, efek kepariwisataan, treatment, kerugian produktivitas, dan biaya surveilans serta pengujian. OIE menargetkan dunia bebas dari rabies pada tahun 2030.

Sebaran penyakit rabies terjadi di berbagai negara, termasuk di Asia, wilayah Asia Tenggara dan Indonesia. Rabies melintas batas negara dan benua. Wabah rabies di Malaysia yang berbatasan langsung dengan Thailand terjadi tahun 1995-1996 (Loke et al., 1998). Wabah penyakit rabies menjalar ke Perlis, Pulau Penang dan Kedah tahun 2015 dengan insidensi $0.10 \%$ (Bamaiyi, 2015). Selain di Semenanjung, Serawak, wilayah Malaysia yang berbatasan dengan provinsi Kalimantan Barat yang semula bebas rabies juga kemasukan penyakit pada tahun 2017 (Bernama, 2020).

Angka kematian karena rabies di Indonesia masih cukup tinggi antara 100 hingga 156 orang per tahun. Dari 34 propinsi yang ada, 8 propinsi telah dinyatakan sebagai zona yang telah bebas dari penyakit rabies dan bertambah terus sebagai upaya pengendalian bersama penyakit rabies. Selang waktu tahun 2015-2019 terjadi akumulatif 544 orang meninggal karena rabies dengan kasus kematian tertinggi di Sulawesi Utara, Kalimantan Barat, Sulawesi Selatan, Sumatera Utara dan Nusa Tenggara Timur. Kejadian luar biasa (KLB) terakhir terjadi di Propinsi Nusa Tenggara Barat tahun 2019.

Indonesia memiliki beberapa laboratorium diagnostik milik pusat maupun pemerintah daerah untuk pengujian sampel rabies yang berasal dari hewan penular rabies (HPR). Balai Besar Veteriner Maros setiap tahunnya menerima kiriman dan aktif mengambil sampel dari wilayah layanan untuk pengujian rabies.

Tulisan ini dibuat dengan maksud untuk mengetahui hasil pengujian sampel otak anjing dan kucing, proporsi dan rasio hasil uji dari sampel kiriman Dinas yang menangani pembangunan peternakan maupun dari kegiatan layanan aktif.

\section{METODE}

Kajian dilakukan secara retrospektif terhadap hasil uji rabies sebanyak 559 sampel berupa otak anjing dan kucing dari 22 kabupaten dan kota telah diuji terhadap rabies pada tahun 2018. Sampel otak anjing berjumlah 514 sampel sedangkan 45 sampel berasal dari 
Prosiding Seminar Nasional Pembangunan dan Pendidikan Vokasi Pertanian

Politeknik Pembangunan Pertanian Manokwari, 31 Juli 2021

e ISSN : 2774-1982

DOI : https://doi.org/10.47687/snppvp.v2i1.170

otak kucing tersangka rabies. Sebanyak 427 sampel berasal dari kiriman, sedangkan 132 berasal dari kegiatan layanan tim surveilans Balai Besar Veteriner (BBVet) Maros. Semua sampel otak segar diperiksa di Laboratorium Virologi dengan metode FAT.

Metode pengujian FAT dilakukan dengan memotong bagian otak, serebelum, hipokampus, kortek atau medula oblongata setebal $0,5 \mathrm{~cm}$ untuk dibuat preparat sentuh pada obyek gelas. Preparat sentuh dari potongan bagian otak anjing atau kucing direndam dalam larutan aseton dan disimpan pada suhu $-20{ }^{\circ} \mathrm{C}$ selama 20 menit. Preparat sentuh kemudian dikeringkan pada suhu kamar untuk selanjutnya ditetesi dengan konjugat. Preparat sentuh kemudian dicuci dengan larutan PBS ber-pH 7,2-7,4 dan dilakukan hingga 3 kali pembilasan. Preparat sentuh dikeringkan dan ditetesi larutan mounting satu tetes serta ditutup cover glass untuk diamati di bawah mikroskop FAT. Dinyatakan positif rabies bila terjadi pendaran cahaya flouresen dengan warna kehijauan pada preparat yang diamati di bawah mikroskop dengan pembesaran lensa obyektif 20X atau 40X.

\section{HASIL DAN PEMBAHASAN}

Pengujian rabies dengan metode FAT merupakan gold standard yang digunakan untuk diagnosa rabies (Kasempimolporn et al., 2011). Metode uji ini relatif mudah dan cepat dilakukan serta memiliki sensitifitas yang sangat baik disamping spesifisitasnya. Sensitifitas uji FAT untuk rabies adalah sebesar 98,26\% dengan nilai prediktif negatif 97,29\% dan nilai prediktif positif sebesar 98,26\% (Ehizibolo et al., 2009). Uji FAT memiliki spesifitas 100\% (Bogia et al., 2012).

Berdasarkan sebanyak 559 sampel otak anjing dan kucing yang diuji dengan FAT di Laboratorium Virologi BBVet Maros menunjukkan hasil positif rabies sebanyak 285 sampel. Rincian hasil pengujian FAT dari 22 kabupaten/kota tertera pada Tabel 1. Proporsi uji positif FAT rabies secara keseluruhan dari 22 kabupaten dan kota adalah sebesar $50,98 \%$ atau dengan kata lain ratio uji menunjukkan positif rabies $51 \%$ dan $49 \%$ negatif rabies.

Pada anjing yang dicurigai rabies, proporsi rabies sebesar 52,92\% dari 514 sampel otak yang diuji FAT. Ratio uji pada sampel otak anjing adalah 53\% positif berbanding $47 \%$ negatif FAT (Gambar 1). 


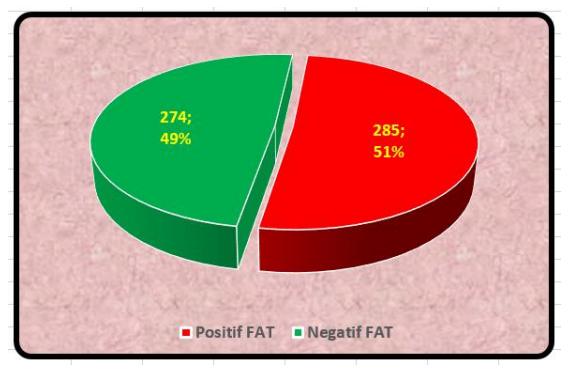

Gambar 1. Ratio hasil uji FAT

Tabel 1. Hasil pengujian sampel rabies

\begin{tabular}{lcccccc}
\hline Kabupaten/Kota & $\begin{array}{c}\text { FAT } \\
\text { positif } \\
\text { sampel } \\
\text { pasif }\end{array}$ & $\begin{array}{c}\text { Jumlah } \\
\text { sampel } \\
\text { pasif }\end{array}$ & $\begin{array}{c}\text { FAT } \\
\text { Positif } \\
\text { Sampel } \\
\text { aktif }\end{array}$ & $\begin{array}{c}\text { Jumlah } \\
\text { sampel } \\
\text { aktif }\end{array}$ & $\begin{array}{c}\text { Total } \\
\text { FAT } \\
\text { positif }\end{array}$ & $\begin{array}{c}\text { Jumlahsampel } \\
\text { pasif \& aktif }\end{array}$ \\
\hline Toraja Utara & 200 & 370 & 6 & 20 & 206 & 390 \\
Tana Toraja & 22 & 32 & 17 & 48 & 39 & 80 \\
Kota Palopo & 1 & 2 & 0 & 0 & 1 & 2 \\
Luwu Utara & 2 & 2 & 0 & 0 & 2 & 2 \\
Luwu & 0 & 1 & 0 & 0 & 0 & 1 \\
Luwu Timur & 1 & 1 & 0 & 0 & 1 & 1 \\
Pinrang & 1 & 1 & 0 & 0 & 1 & 1 \\
Pare-pare & 1 & 1 & 0 & 0 & 1 & 1 \\
Bulukumba & 2 & 6 & 0 & 0 & 2 & 6 \\
Selayar & 1 & 1 & 0 & 0 & 1 & 1 \\
Maros & 5 & 5 & 0 & 0 & 5 & 5 \\
Pangkep & 2 & 2 & 0 & 0 & 2 & 2 \\
Mamasa & 1 & 1 & 0 & 0 & 1 & 1 \\
Palu & 0 & 1 & 0 & 0 & 0 & 1 \\
Banggai & 0 & 0 & 1 & 1 & 1 & 1 \\
Poso & 0 & 0 & 0 & 4 & 0 & 4 \\
Manokwari & 0 & 1 & 0 & 0 & 0 & 1 \\
Bone Bolango & 0 & 0 & 0 & 4 & 0 & 0 \\
Manado & 0 & 0 & 17 & 40 & 17 & 40 \\
Minahasa & 0 & 0 & 1 & 5 & 1 & 5 \\
Minahasa & 0 & 0 & 1 & 5 & 1 & 5 \\
Selatan & & & & & & \\
Tomohon & 0 & 0 & 3 & 5 & 3 & 5 \\
\hline \multicolumn{1}{c}{ Total } & 239 & 427 & 46 & 132 & 285 & 559 \\
\hline
\end{tabular}

Panichabhongse (2001) melakukan analisa hasil pengujian FAT rabies pada anjing di Thailand periode tahun 1993-1999, hasilnya menunjukkan bahwa dari 40.640 sampel otak anjing yang dikirim ke laboratorium diagnostik menunjukkan $87 \%$ positif rabies.

Rabies merupakan penyakit yang menyerang hewan berdarah panas. Panichabhongse (2001) menemukan sebanyak 57\% dari sampel otak sapi yang dicurigai rabies di Thailand, positif FAT nya terhadap rabies. Baby et al. (2015) menemukan rabies 
Prosiding Seminar Nasional Pembangunan dan Pendidikan Vokasi Pertanian

Politeknik Pembangunan Pertanian Manokwari, 31 Juli 2021

e ISSN : 2774-1982

DOI : https://doi.org/10.47687/snppvp.v2i1.170

terjadi pada ayam (Gallus domesticus), dengan hasil uji positif pada pengujian otaknya dengan FAT dan polymerase chain reaction (PCR).

Rabies di wilayah layanan BBVet Maros tidak hanya terjadi pada anjing tetapi juga pada kucing pada tahun 2018. Rabies pada kucing banyak terjadi di Kabupaten Toraja Utara dengan proporsi rabies sebesar 28,89\% dari 45 sampel otak kucing atau ratio uji $29 \%$ positif rabies dan $71 \%$ negatif rabies. Dibandingkan dengan rabies pada kucing, proporsi rabies pada anjing di Kabupaten Toraja Utara sebesar 55,33\%. Ratio pengujian menunjukkan 55\% positif rabies, 45\% negatif rabies (Gambar 2). Dari 200 otak yang positif FAT, sebanyak $93,5 \%$ terjadi pada anjing dan $6,5 \%$ terjadi pada kucing

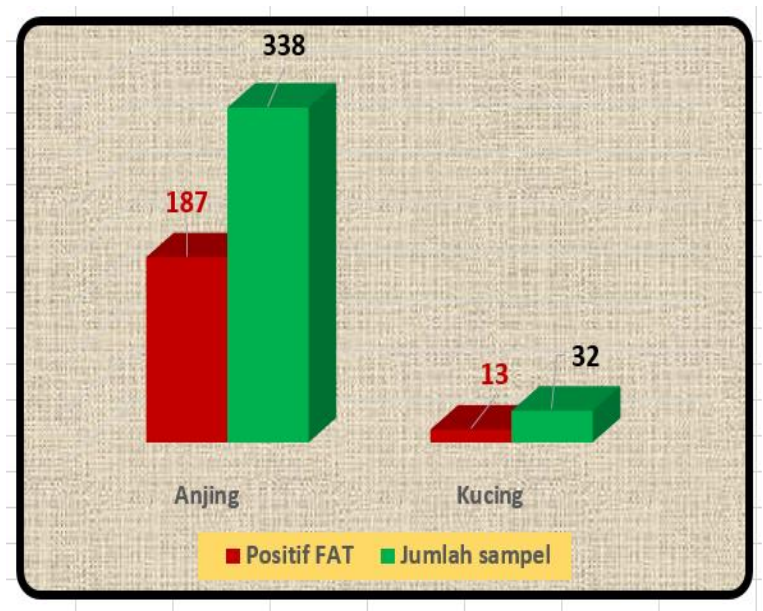

Gambar 2. Hasil pengujian sampel rabies pada anjing dan kucing dari Toraja Utara

Schaefer et al. (2002) menemukan pertama kali kasus rabies pada kucing umur 2 tahun di Brazil Selatan yang mendadak mengigit pemilik dan hewan lain di sekitarnya. Kucing secara klinis mengalami ataksia dan paralisa posterior serta mati dalam waktu 6 hari setelah menggigit tuannya. Mshelbwala et al. (2014), melakukan pemeriksaan menggunakan rapid imunokromatografi serta FAT pada kucing setelah mati dengan gejala agresif dan kedua bola matanya penuh discharge, dengan hasil positif rabies.

Proporsi rabies pada anjing lebih besar dibandingkan dengan rabies pada kucing seperti yang terjadi di kabupaten Toraja Utara. Frekuensi kejadian rabies pada anjing di daerah enzootic dog rabies area (EDRA) 1,5\% lebih tinggi dibandingkan pada kucing (Crozet et al., 2020)

Berdasarkan data hasil pengujian bulanan rabies, frekuensi tertinggi rabies terjadi pada bulan Oktober yang terlihat melonjak tajam dibandingkan bulan yang lainnya (Gambar 3). Pergerakan anjing saat musim kawin atau rendahnya antibodi rabies pada 
Prosiding Seminar Nasional Pembangunan dan Pendidikan Vokasi Pertanian

Politeknik Pembangunan Pertanian Manokwari, 31 Juli 2021

e ISSN : 2774-1982

DOI : https://doi.org/10.47687/snppvp.v2i1.170

populasi anjing saat bulan Oktober diduga sebagai risk factor melonjaknya kasus rabies pada bulan Oktober.

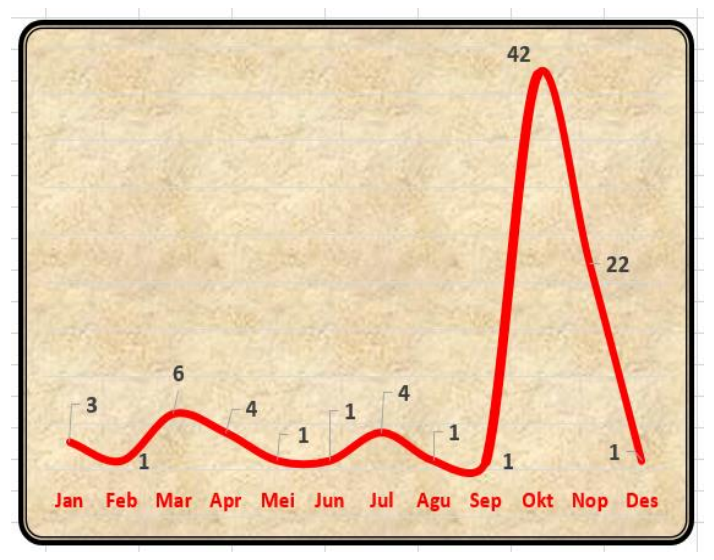

Gambar 3. Frekuensi Rabies berdasarkan hasil uji FAT positif per bulan

Penelitian biomolekular terhadap nukleotida virus rabies penting untuk mengetahui asal muasal dan keterkaitan virus dengan yang ada di pulau atau negara lain. Virus rabies di Bali memiliki homologi 98,5-98,6\% dengan virus rabies asal Sulawesi serta 98,2\% homolog dengan virus rabies Kalimantan (Dibia et al., 2014). Virus rabies di Serawak, Malaysia bagian timur memiliki homologi $98 \%$ dengan virus rabies asal Kalimantan dan Sulawesi (Fairul et al., 2019).

\section{KESIMPULAN DAN SARAN}

Rabies di wilayah layanan Balai Besar Veteriner Maros dalam tahun 2018 terjadi pada hewan anjing dan kucing dengan proporsi positif 50,98\%. Dari 17 kabupaten dan kota lokasi kasus rabies, kasus rabies tertinggi terjadi di kabupaten Toraja Utara sebesar 72,28\% dari total 285 kasus positif. Dari 200 kasus positif rabies di Toraja Utara, 93,5\% terjadi pada anjing, sedangkan 6,5\% terjadi pada kucing. Rabies terjadi setiap bulan dengan puncak frekuensi kasus terjadi pada bulan Oktober.

Mengingat rabies terjadi pada hewan anjing dan kucing maka disarankan agar vaksinasi rabies secara intensif dilakukan pada anjing dan kucing. Untuk mencegah terjadinya epidemik rabies pada bulan Oktober, maka vaksinasi massal rabies hendaknya dilakukan sebelum Oktober. Kajian perlu dilakukan untuk mencari risk factor yang berasosiasi dengan terjadinya epidemi rabies pada bulan Oktober. 
Prosiding Seminar Nasional Pembangunan dan Pendidikan Vokasi Pertanian

Politeknik Pembangunan Pertanian Manokwari, 31 Juli 2021

e ISSN : 2774-1982

DOI : https://doi.org/10.47687/snppvp.v2i1.170

\section{DAFTAR PUSTAKA}

Anonimous. (2020). Rabies in cat in Haly. Prelimanary outbreak in assesment. Depart for Environment, Food and Rural Affair Animal and Plant Helath Agency. Advice Services-International Disease Monitoring.

Baby, J., Mani, R.S., Abraham, S.S., Thankhappen, A.T., Pillai, P.M., Anand, A.M., Madhusudana, S.N., Ramachandran, J., \& Sreekumar, S. (2015). Natural rabies infectious in a domestic fowl (Gallus domesticus): A report from India. Plos Negl Trop Dis. 9(7): 1-6.

Bamaiyi, P.H. (2015). 2015 outbreak of canine of rabies in Malaysia: Review analysis and perspectives. $J$ Vet Adv. 5 (12): 1181-1190.

Bernama. (2020). Dog bit Sarawak boy confirm to have rabies. Malay-Mail, 20-05.

Bogia, S.Y., Kardena, I.M., Sukada, I.M., \& Supartika, K.E. (2012). Perbandingan sensitivitas dan spesifisitas uji pewarnaan Seller's dan flourescent antibody technique (FAT) dalam mendiagnosa rabies pada anjing di Bali. Indonesia Medicus Veterinus. 1(1): 12-21.

Crozet, G., Riviere, J., Canini, L., Cliquet, F., Robardet, E., \& Dufour, B. (2020). Evaluation of the worldwide occurrence of rabies in dogs and cats using a simple and homogenous framework for quantitative risk asessment of rabies reintroduction in disease free areas through pet movement. Vet Sci. 7(4): 1-27.

Dibia, I.N., Sumiarti, B., Susetya, H., \& Putra, A.A.G. (2014). Phylogenetic analysis of rabies virus in Bali. Buletin Veteriner. 26(84): 1-14.

Ehizibolo, D.O., Nwosuh, C.I., Ehizibolo, E.E., \& Kia, G.S.N. (2009). Comparison of the fluorescent antibody test and direct microscopic examination for rabies diagnosis at The National Research Institute, Vom, Nigeria. African J Biomedic Res. 12(1): 73-76.

Fairul, F.M.Y., Syamsiah, A.A.S., Roslina, H., Norazura, A.H., Fikri, A.Y., Syamsid, N.N., \& Faizah, H.M.S. (2019). Phylogenetic analysis of Rabies viruses detected in Malaysia. Malaysian J Vet Res. 10(2): 32-38.

Kasempimolporn, S., Saengseesom, W., Huadsakul, S., Boochang, S., \& Sitprija, V. (2011). Evaluation of rapid immunochromatographic test strip for detection of rabies virus in dog saliva samples. J Vet Diagn Invest. 23(6): 1197-1201.

Loke, Y.K., Murugesan, E., Suryati, A., \& Tan, M.H. (1998). An outbreak of rabies in the State of Terengganu 1995-1996. Med J Malaysia. 53(1): 97-100.

Mshelbwala, P.P., Nlebedum, U., Peterside, K.R., Yakubu, A.J., Ifukibot, U., \& Onyiche, E.T. (2014). A case rabies in one month old kittens in South East Nigeria. $J$ Veterinar Sci Technol. 5(2): 1-3. 
Prosiding Seminar Nasional Pembangunan dan Pendidikan Vokasi Pertanian

Politeknik Pembangunan Pertanian Manokwari, 31 Juli 2021

e ISSN : 2774-1982

DOI : https://doi.org/10.47687/snppvp.v2i1.170

Panichabhongse, P. (2001). The epidemiology of rabies in Thailand. A thesis presented in partial fulfillment of the requirement fot the degree of master vet studies. Massy Univ, New Zealand.

Schaefer, R., Caldas, E.P., Schmit, E., King, A.A., \& Roche, P.M. (2002). First case of cat rabies in southtern Brazil for 11 years. Vet Rec. 150(7): 216-217. 